\title{
Hva er «original» vitenskap?
}

\author{
Medisinsk forskning frembringer en stor mengde data, men altfor sjel- \\ den forekommer det genuint nye innsikter. For å unngå at forskningen \\ bare reproduserer seg selv, bør både planlegging, innsamling og tolking \\ av data ledsages av teoretisk refleksjon. Original viten frembringes først \\ ved analyser som er tilstrekkelig adekvate, presise og dype.
}

Dagens biomedisinske forskning kjennetegnes av et misforhold mellom en økende mengde forskningsdata på den ene side og mangelen på vesentlige nye bidrag til forståelsen av vanlige og komplekse helseproblemer på den annen. Dette misforholdet mellom empiri og forståelse gir grunn til faglig ubehag (1). Medisinsk fagutvikling kan ikke lykkes utelukkende ved produksjon av originaldata, men er avhengig av at det utvikles original tenkning som kan fylle et stadig mer merkbart teoretisk vakuum (2-4). Vi trenger teoretiske forståelsesrammer som kan gjøre de stadig økende mengder av fakta begripelige og som kan åpne for overordnede perspektiver. Uten det kan vi gå glipp av fenomener som er virksomme på andre nivåer enn der data genereres (2). Trenger vi et paradigmeskifte for å kunne fylle tomrommet mellom mengden av foreliggende data og den betydning disse måtte ha $(3,4)$ ?

\section{Original empiri og teori}

$\mathrm{Vi}$ vil hevde at det er behov for en annerledes forståelse av ordet «original» enn den som vanligvis brukes i medisinen. Brukt om «data» refererer «original» vanligvis til fakta fremskaffet ved faglig ortodokse fremgangsmåter, altså medisinens konvensjoner for hvordan pålitelige data skapes, bearbeides, tolkes og presenteres. Originalitet knyttes slik opp mot vitenskapens objekter og om hvorvidt tilsvarende observasjoner har vært rapportert tidligere. «Original» brukt om «tanke» innebærer derimot et rom for faglig uortodokse resonnementer - altså nye og kan hende «troskritiske» måter å begrepsfeste og forstå fenomener og funn på. Originalitet knyttes dermed opp mot forståelsesaspektet ved vitenskapen, dog uten at man gir slipp på en nøktern forankring i tilgjengelig empiri.

Vi tror ikke det er konstruktivt å trekke et skarpt skille mellom empiriske og teoretiske originalbidrag i vitenskapelig sammenheng. Empiriske bidrag må bedømmes ut fra teoretisk nivå - ethvert empirisk arbeid bygger på (implisitte eller ekspli- sitte) teoretiske forutsetninger som styrer valg av perspektiv, problemstilling og metode. Tilsvarende kan teoretisk forskning som er basert på refleksjoner rundt foreliggende empiri ikke kategoriseres som ikke-empirisk, selv om man ikke har samlet inn nye data for anledningen. Slike bidrag må bedømmes med henblikk på om det empiriske datagrunnlag det henvises til holder mål og om argumentet kan utfordres av andre (ev. fremtidige) datasett. Et skille mellom teoretiske og empiriske bidrag kan, slik vi ser det, bidra til en dikotomi som ikke fremmer kritisk vitenskapelig tenkning og radikal akademisk kritikk. Vi foreslår derfor den ikke-dikotomiserende betegnelsen «analytisk forskning» som sjangernavn for vitenskapelig nytenkning. Analytisk dybde og presisjon blir da kjennetegn på kvalitet, mens overfladiskhet eller analytisk unnlatelse - det å la være å belyse perspektiver som klart spiller en rolle for det fenomen man studerer (5) - kjennetegner et arbeid som ikke holder mål.

\section{Original artikkel}

I en lederartikkel i Tidsskriftet nr. 1/2009 drøfter Charlotte Haug hva en originalartikkel er (6). Vi mener at en originalartikkel kjennetegnes av at den bidrar vesentlig til forståelsen av og gir innsikt i medisinske fenomener. Det kan skje i kraft av nye data $o g$ nye spørsmål eller nye resonnementer som utvider forståelsesrommet og åpner for integrering av eksisterende empiri, gjerne fra uvante områder, i nye teoretiske sammenhenger.

Det kan bli en utfordring for Tidsskriftets redaksjon å vurdere manuskripter i den nye originalkategorien det her er snakk om. Én vei å gå er å be forfatterne i følgebrevet redegjøre spesielt for hvorfor de mener manuskriptet er et originalt vitenskapelig bidrag, til forskjell fra en «oversiktsartikkel» eller «kronikk».

Det kan også være fruktbart å la forfatterne selv foreslå 1-2 fagfeller, med forutsetninger for å vurdere arbeidets origina- litet og konsistens spesielt, i tillegg til de fagvurdererne Tidsskriftet selv ønsker å bruke.

\section{Tor-Johan Ekeland \\ Høgskulen i Volda \\ Linn Getz}

Institutt for samfunnsmedisin

Norges teknisk-naturvitenskapelige universitet og

Landspitali universitetssykehus

Reykjavik

Irene Hetlevik

Institutt for samfunnsmedisin

Norges teknisk-naturvitenskapelige universitet

\section{Anna Luise Kirkengen}

anlui-k@online.no

Institutt for samfunnsmedisin

Norges teknisk-naturvitenskapelige universitet og

Institutt for samfunnsmedisin

Universitetet i Tromsø

9037 Tromsø

og

Akershus universitetssykehus

Edvin Schei

Institutt for samfunnsmedisin

Universitetet i Bergen

og

Universitetet i Tromsø

Elling Ulvestad

Haukeland universitetssykehus

og

Gades Institutt

Universitet i Bergen

Arne Johan Vetlesen

Filosofisk institutt

Universitetet i Oslo

Forfatterne utgjør tenketanken ved allmennmedisinsk forskningsenhet ved Norges teknisk-naturvitenskapelige universitetet.

Oppgitte interessekonflikter: Ingen

Litteratur

1. Getz L, Kirkengen AL, Hetlevik I. Too much doing and too little thinking in medical science! Scand J Prim Health Care 2008; $26: 65-6$.

2. Rose S. The future of the brain: the promise and perils of tomorrow's neuroscience. Oxford: Oxford University Press, 2005.

3. Marian AJ. Surprises of the genome and «personalized medicine». J Am Coll Cardiol 2008; 51: 456-8. doi: 10.1016/j.jacc.2007.10.020.

4. Orosz C. Tending Adam 's garden. Graft 2000; 3 339-40.

5. Farmer $\mathrm{P}$, Nizeye $\mathrm{B}$, Stulac $\mathrm{S}$ et al. Structural violence and clinical medicine. PLoS Med 2006; 3: e449. doi: 10.1371/journal.pmed.0030449.

6. Haug C. Raskere, bedre, strengere. Tidsskr Nor Legeforen 2009; 129: 11

Manuskriptet ble mottatt 14.1. 2009 og godkjent 12.3. 2009. Medisinsk redaktør Anne Kveim Lie. 